\title{
Önkormányzati kommunikáció a COVID-19 világjárvány okozta krízishelyzetben
}

\author{
Baranyai Nóra ${ }^{1, *}$, Barsi Boglárka ${ }^{1}$, Nárai Márta ${ }^{1,2}$ \\ ${ }^{1}$ KRTK Regionális Kutatások Intézete, Győr, Magyarország \\ ${ }^{2}$ Széchenyi István Egyetem, Győr, Magyarország \\ Beérkezett: 2021. július 15.; Elfogadva: 2021. augusztus 24.
}

\begin{abstract}
Összefoglalás
A COVID-19-járvány kezelésében az önkormányzatok kiemelkedő szerepet kaptak. Tanulmányunkban azt kívánjuk bemutatni, hogy ebben a krízishelyzetben, a járvány magyarországi három hulláma során az önkormányzatok milyen módon kommunikáltak különböző online felületeken (települési honlapok, települési és polgármesteri Facebookoldalak) a lakossággal. A változó járványhelyzet, a reagálás gyorsaságának szükségessége felhívta a figyelmet arra, hogy milyen fontos az önkormányzatok és a lakosok közötti kommunikáció, illetve az új kommunikációs csatornák alkalmazása. A településtípusok között nem mutatkozott nagy különbség a kommunikáció mikéntjére, jellegzetességeire vonatkozóan, bár a feladatmennyiséget tekintve nyilván más-más kihívásokkal kellett az eltérő méretű önkormányzatoknak szembenézniük.
\end{abstract}

Kulcsszavak: helyi önkormányzatok, COVID-19, online kommunikáció

\section{Local government communication in a crisis situation caused by the COVID-19 pandemic}

\author{
Nóra Baranyai ${ }^{1}$, Boglárka Barsi ${ }^{1}$, Márta Nárai ${ }^{1,2}$ \\ ${ }^{1}$ Institute for Regional Studies, Centre for Economic and Regional Studies, Győr, Hungary \\ ${ }^{2}$ University of Győr, Győr, Hungary
}

\begin{abstract}
Summary
Local governments had a key and prominent role in tackling COVID-19 pandemic. Their task was to take short-term measures quickly, to organize protection and care for those in need. The main objective of our paper is to present, how local governments communicated with their inhabitants on various online interfaces in this crisis situation. Our analysis covers 54 settlements representing all the different levels of the settlement network from large cities to small villages. We examined the webpages and Facebook pages of local governments and mayors, firstly during the first wave, then during the second and the third waves of the pandemic.

Recognizing their responsibility, local governments clearly tried to provide all the information to the inhabitants as quickly as possible. They considered the online interfaces the most effective, but the online communication had typically been complemented by information published on more traditional channels as well. There were no significant difference in terms of the way and characteristics of communication among the different types of settlements, although local governments of different sizes obviously had to face different challenges in terms of the amount of tasks they had to tackle.

The communication process was a very difficult task because of the lack of information and the not entirely transparent data provision. Even on the Facebook pages especially suitable for this purpose, interactivity rumbled, and in many cases the questions and suggestions of the inhabitants remained unanswered. It is instructive that, with few exceptions, local authorities do not place emphasis on surveying local needs and opinions.

The full range of measures and contact with the public cannot be evaluated from local governmental online communication, but it can be said that the publication of information has changed thematically and has significantly de-
\end{abstract}


clined in volume and frequency since the first month of the epidemic in March 2020. There were local governments that performed excellently in online communication, i.e. they published regular and relevant information, but there were also some (mainly small settlements) that did not use these channels at all or after a while. The latter may be explained by the fact that the population of the settlement - due to its age composition or the characteristics of Internet use - can be effectively informed mainly through other, traditional channels. There is little doubt that the lack of information available to local governments, declining local empowerment, and growing central management in epidemic management may also have resulted in less and less communication at the local level.

Keywords: local governments, COVID-19, online communication

\section{Bevezetés}

A kommunikáció, az információ átadása, közvetítése nemcsak egy világjárvány idején játszik fontos szerepet, de krízishelyzetben szerepe még fontosabbá válik. Egy krízis során a közvélemény egyszerre várja el az azonnali válaszadást, látványos intézkedéseket, kész forgatókönyveket, professzionalizmust és társadalmi szolidaritást (Kriskó 2012). A helyi önkormányzatok állnak a különböző kormányzati szintek közül a legközelebb a lakosokhoz, ezért a velük való kommunikáció kiemelkedően fontos feladatuk. A jó kormányzás fogalma magában foglalja az olyan demokratikus értékeket és intézményrendszereket, mint a jogállamiság, a részvétel és a transzparencia. A decentralizáció pedig kutatások szerint pozitív hatással van a polgárközelségre, a részvételre, az információáramlásra és a politikai szocializációra (Pálné Kovács 2013). A megfelelő, hiteles tájékoztatás mellett az önkormányzatoknak a kétirányú kommunikációra kellene törekedniük, azaz nyitottabbnak és hajlandóbbnak kellene lenniük az állampolgárok visszajelzéseire, észrevételeire, kérdéseire (Belényesi 2011), lehetőséget kellene biztosítaniuk az interaktivitásra, ez teremthetne igazi partneri viszonyt az állampolgárok felé. Ezt a fajta interaktivitást, illetve kétirányú kommunikációt napjainkban az infokommunikációs technológiák rohamos fejlődése, az internet elterjedése lehetővé teszi/tenné az önkormányzatok számára. Ráadásul az Európai Bizottság ez év (2021) márciusában bemutatott, az EU digitális évtizedére irányuló elképzeléseinek egyik sarokpontja a kormányzás területe, és a megfogalmazott digitális alapelvek magukban foglalják a digitális jogokat, melyek között a „véleménynyilvánítás szabadsága, beleértve a különböző, megbízható és átlátható információkhoz való hozzáférést" is szerepel (Európai Bizottság 2021).

A digitális átalakulásra való törekvést és így az önkormányzati kommunikáció IKT általi fejlesztését nagyban elősegíti és egyben meg is követeli, hogy az ezredfordulóra ugrásszerüen megnőtt az internethasználók száma. Ennek következtében az internet szerepéról, funkciójáról és használatáról való gondolkodás és attitüd jelentősen megváltozott. Az internet egyre inkább olyan platformmá válik, ahol nemcsak a nagy, központi szereplők, hanem a kisebb szereplők is fontos szerepet játszanak, és sokkal nyitottabb a felhasználói aktivitás és szükséglet, mint korábban volt (web 2.0). Néhány platform eleve olyan tartalmat kínál, melyet a felhasználók hoznak létre aktivitásuk során (pl. közösségi média). Más platformok esetén a platform létrehozói maradnak a tartalom létrehozói, de lehetôvé teszik az aktív részvételt és interakciókat az oldalaikon. Az internetnek ez az új korszaka egy sokkal interaktívabb felhasználást eredményezett, mint a régebbi, hagyományos weboldalak, ugyanakkor még ezek sem teszik lehetővé a polgárok tényleges, lényegi bevonását a politika formálásába (Bene 2019).

\section{Elméleti alapok}

Bár az új kommunikációs technológiákban rejlő lehetőségeket először a magánszektor fedezte fel, a közösségi média a politikai élet és a lakosságnak információt nyújtó közintézmények figyelmét is felkeltette, mint a nyitott és transzparens közigazgatás, a közszolgáltatások nyújtásának és a különböző érdekhordozókkal való kapcsolattartásnak egy lehetséges eszköze (Sobaci 2016).

Korábbi kutatások tapasztalatai alapján a kormányok a következő okok miatt használják a közösségi médiát:

- különböző eseményekre való toborzás

- a lakosság és a nyilvánosság elérése, megszólítása

- információk terjesztése szélesebb nyilvánosság számára

- információ megosztása a különböző kormányzati szereplők számára

- közösségi részvétel megerősítése és népszerüsítése

- transzparencia (Grabam-Avery-Park 2015).

A kormányzati szereplők és intézmények tehát egyre inkább használják a közösségi médiát és az internetes kommunikációt, hogy kitűzött céljaikat elérhessék. Ezek az új technológiák fokozatosan átalakítják a közszféra régi modelljét, számtalan lehetőséget kínálva a transzparencia és a bizalom növelésére, a lakosság részvételére és a közügyekbe való bevonódásának növelésére, valamint javítják a szervezeten belüli és szervezetek közötti együttmúködést (Karakiza 2015).

A korábban elképzelhetetlen mobilizációs kapacitásával a közösségi média sokkal szélesebb perspektívát kínál a közszféra intézményei számára kommunikáció terén helyi szinten is, ugyanakkor alkalmazása új kockázatokat és kihívásokat is jelent. Például a közösségi média minden, a helyi önkormányzattal szemben támasztott igényt, panaszt vagy eseményt felnagyíthat és pillanatok alatt emberek tömegeihez juttathat el, ami rombolhatja az adott település, önkormányzat megítélését (MedinaDiaz 2016). 
Az információhiány viszont bizalomhiányhoz, legitimációs deficithez és érdektelenséghez vezethet, növeli a távolságot a helyi önkormányzat és a lakosok között (Bajnok 2014). Az intézményi bizalom tekintetében a helyi önkormányzatok autonómiája különösen fontos szerepet játszik, de a bizalmat erősítheti vagy rombolhatja a helyi szolgáltatások színvonala, az épített környezet, a gazdaság fejlettsége, a helyi társadalom összetétele is. A gazdasági és társadalmi kontextus mellett a helyi kormányzás minősége és a helyi bizalomépítő erőfeszítések hatékonysága sem mellékes (Pálné Kovács 2019). Jelentős probléma, hogy a helyi önkormányzatok nem tekintik fontos feladatnak a helyi szolgáltatásokról, közszolgáltatásokról való adat- és információközlést. Ez a fajta szemléletmód rontja a múködési hatékonyságot. A helyi önkormányzatok kommunikációjának fontos célja ugyanis az intézményi célok elfogadtatása, az adatok közlése, a múködés átláthatóságának biztosítása, a szabályozások, rendelkezések és információk világos és átfogó értelmezése, mely a hitelességen keresztül erősíti a lakosság bizalmát. A kommunikáció azonban nem lehet egyoldalú, célja kell hogy legyen a polgárok számára a véleményük és gondolataik kifejtésének biztosítása (Rákóczi 2006). A megfelelő információ nyújtása azért is fontos, mert ez teszi lehetővé és bátorítja a lakosságot arra, hogy aktívan részt vegyen a település fejlesztésében és a települést érintő problémák megoldásában (Belényesi 2011). Az állampolgárok oldaláról a tájékozódás és a közügyek befolyásolásának igénye, míg a helyi politika oldaláról a hiteles tájékoztatás, információnyújtás és a kétoldalú kommunikációra törekvés lenne a feltétele a tényleges állampolgári aktivitásnak. Ahogy a jelenleg hatályos önkormányzati törvény (2011. évi CLXXXIX. törvény Magyarország helyi önkormányzatairól, 6. \$) is megfogalmazza „A helyi önkormányzat feladatai ellátása során: a) támogatja a lakosság önszerveződő közösségeit, együttmúködik e közösségekkel, biztosítja a helyi közügyekben való széles körü állampolgári részvételt", melynek tehát a tájékoztatás és a kommunikáció is fontos eleme.

A helyi önkormányzatok legitimációja függ tehát a lakosságtól, a lakosság döntéshozatalban való részvételi szándékától, valamint attól, hogy milyen mértékben kívánják a település polgárai a döntéshozatalt befolyásolni és ellenőrizni (Pálné Kovács 2019).

Az adott település lakossága jogosan várja el, hogy a helyi önkormányzat megfelelő minőségű és szintű információt szolgáltasson a közügyekról, mivel egyik alapvető feladata a folyamatos információnyújtás a polgárok számára, és a kétirányú, interaktív párbeszéd biztosítása. Ezen információ minősége és mennyisége határozza meg a települési kohéziót, a települési identitást és a településhez való kötődést. A helyi önkormányzat imázsát nagymértékben befolyásolja a külső és belső kommunikációs stílusa, viselkedése, akciói, filozófiája, kultúrája és szerkezete, valamint a közszolgáltatások minősége (Rákóczi 2009). A fentieket figyelembe véve tehát nem beszélhetünk megfelelő kommunikációról, ha az üzeneten és az üzenet nyújtóján kívül nem fordítanak figyelmet az üzenet fogadójára, annak jellemzőire, szükségleteire, kompetenciáira és elvárásaira. Az egyirányú kommunikáció, önmaga a tájékoztatás nem feltétlenül hatékony, ugyanis az üzenet végső értelme nem maga az üzenet, hanem az üzenet fogadója, tehát a helyi lakos, polgár. Ő az, aki értelmet ad az üzenetnek, ezért a párbeszéd a helyi kormányzati szereplők és a lakosság között elkerülhetetlen (Jenei 2010). A helyi lakosok számára frusztráló egy távoli hivatallal való egyirányú, kérdésekre nem válaszoló kapcsolat. A manapság rendelkezésre álló számtalan interaktív technika jelentősen megkönnyíti a bizalom kialakulásához szükséges kétirányú kommunikáció lehetőségének megteremtését. Magyarországon a helyi lakosok jó része többségében az újságokból, televízióból és barátoktól értesül a helyi önkormányzat múködéséről. A hagyományos média (nyomtatott sajtó, tv, rádió) azonban egyirányú kommunikációs csatorna, míg az internet biztosította új technikák lehetővé teszik a kétirányú kommunikációt is. A helyi önkormányzatoknak nagyobb hangsúlyt kell fektetni arra, hogy fogadják a helyi lakosok visszajelzéseit, és nyitottabbnak kell lenniük arra, hogy kérdéseket fogadjanak és válaszoljanak meg (Belényesi 2011). Emellett a közösségi média felületén való lakossági kommunikáció is egyre fontosabbá válik, és olyan rétegeket ér el, melyeket nehéz megszólítani más kommunikációs csatornákon, ilyenek például azok, akiknek igen határozott politikai álláspontjuk van, vagy akik egyáltalán nem érdeklődnek a politika iránt (Bene 2019).

Ahogy az IKT és a webalapú kommunikáció, valamint a közösségi média használata egyre fontosabb szerepet kezdett betölteni a közintézmények életében, a helyi önkormányzatok egyre nagyobb hangsúlyt kezdtek fektetni arra, hogy krízishelyzetekben használják a közösségi médiát (Neely-Collins 2018). Nemzetközi tanulmányok szerint a helyi önkormányzatok egyre nagyobb mértékben használják a különböző weboldalakat és közösségimédia-platformokat általában, és krízishelyzetben is (Merchant-Elmer-Lurie 2011; Mergel 2012; Bernier 2013; Conrado et al. 2016). A közösségi média nyitott, párbeszédre építő jellege eltünteti azokat az akadályokat a lakossággal való kommunikációban, melyekkel a történelem során a kormányzat szembesült (Graham-AveryPark 2015). Az is bebizonyosodott, hogy a polgárok gyakran keresnek valós idejü információkat, valamint instrukciókat, károk elhárítására vonatkozó javaslatokat vészhelyzetek (pl. időjárási, közlekedési vészhelyzet) idején a közösségi média felületein (American Red Cross 2012). Ezért az önkormányzatokkal, kormányzattal szemben a közösségimédia-felületen elvárt információigény jelentősen megnövekedett (Jin-Liu-Austin 2014; Mergel 2012; Neely-Collins 2018). Hughes és Tapia szerint a közösségi média létezése miatt a közösség tagjai sokkal behatóbb módon tudnak részt venni a krízishelyzetek megoldásában, úgy, hogy maguk is gyújtenek, kez- 
deményeznek, kreálnak, megosztanak, keresnek online információkat (Hughes-Tapia 2015). Az állampolgári vagy civil szervezeti kezdeményezések fogadására nem feltétlenül felkészült vagy fogékony a helyi hatalom, van, ahol ezt kritikaként értelmez(het)ik, esetleg politikai indíttatást sejtenek mögötte, és kevésbé fogadják el vagy állnak mellé. Ez feltehetőleg jelentős mértékben függ attól is, hogy a civil társadalom szereplőire miként tekint az önkormányzat (pl. alattvalóként, partnerként, szakértőként stb.), vagy hogy mennyire várja és fogadja el az aktív részvételt, befolyásolást a település lakosságától.

\section{Kutatási elözmények}

A COVID-19 járvány megjelenése óta számtalan nemzetközi vizsgálat született arra vonatkozóan, hogy a (helyi) kormányzat hogyan kommunikál egy világjárvány alatt. Több országban is vizsgálták azt, hogy az információs és kommunikációs technológiákat és a közösségi médiát hogyan lehet és hogyan használják a kormányzatok nemzeti és lokális szinten egy világjárvány során, hiszen ezek a csatornák teszik lehetôvé a leggyorsabb és leghatékonyabb kommunikációt egy krízishelyzetben. Néhány tanulmány átfogó módon vizsgálta a helyi önkormányzatok szerepét és feladatait a járványhelyzetben (Franzke 2020; Finta-Kovács-Pálné Kovács 2020b; Gore et al. 2021), más kutatások a krízis- és kockázatmenedzsmenttel foglalkoztak (Moreno-Fuentes-Lara-Navarro 2020; Park et al. 2020). Ismét mások kifejezetten a COVID-19-hez kapcsolódó ajánlásokat fogalmaztak meg, gyakorlati szempontokat figyelembe véve a helyi (tartományi) válságstratégiák megújításához (TorneoBerse 2020). Jelen kutatáshoz hasonló módon néhány amerikai város esetén vizsgálták a helyi önkormányzat és a lakosság közötti kommunikációt a Twitteren (Zeemering 2021), illetve Vuhanban a Sina Weibon (Yang et al. 2021).

Magyarországon több kutatás vizsgálta a COVID-19 járvány tágabb értelemben vett társadalmi-gazdasági hatásait (Tóth-Hudácskó 2020; Koós 2020), a helyi önkormányzatok szerepét és helyzetét (Kovács 2020b), valamint a kommunikációs gyakorlatokat. Egyes kutatások az oktatás és tanulás helyzetét vizsgálták, kiemelt figyelmet fordítva a közösségi tanulásra (Forray-Kozma 2021). Mások az intézmények és a közszolgáltatások, közigazgatás reakcióját, alkalmazkodását, rezilienciáját (Katona-Petrovics 2021; Balázs 2021), a rendőrség járvány idején játszott szerepét és a szabálysértési jogterület változásait (Skorka 2021), a bizalom kultúráját (GrünhutBodor 2020), a közösségi terek használatát (Jóna 2020), online pénzügyi szolgáltatásokat (Kovács 2020a), a távmunka és a vándormozgalmi mintázatok kapcsolatát kutatták a járványhelyzetben (Lennert 2020). Több tanulmány a közlekedés megváltozott helyzetével foglalkozott (Gertheis 2021; Varjú et al. 2020).

Településeket vizsgáló kutatások is születtek. Szirmai (2021) a nagyvárosok helyzetét vizsgálta a világban a világjárvány idején. Finta és szerzőtársai munkája az önkormányzatok helyzetét vizsgálta átfogó módon a világjárvány idején Magyarországon (tanulmányunk előzménye ez a kutatás volt, Finta-Kovács-Pálné Kovács 2020b), Fekete munkatársaival egy szűkebb térségben, a balatoni üdülőövezetben folytatott kutatást az önkormányzatok válságkezelési gyakorlatáról (Fekete-Dombi-Oláh 2021).

\section{A COVID-19 és a helyi önkormányzatok}

A SARS-CoV-2 koronavírus jelenlegi ismereteink szerint 2019 utolsó hónapjaiban jelent meg a közép-kínai Vuhanban, s olyan szédületes sebességgel terjedt szét a világban, hogy 2020 márciusában az Egészségügyi Világszervezet pandémiává nyilvánította a COVID-19 járványt. A mai napig (2021. augusztus 13.) világszerte 205898243 személyben mutatták ki a kórokozó jelenlétét, s 4341589 fó hunyt el a vírus által okozott betegségekben, illetve azok szövődményeiben (forrás: Johns Hopkins University, https://coronavirus.jhu.edu/map. html). Jóllehet, a tudományos erőfeszítések eredményeként ma már számos vakcina, s egyre hatásosabb gyógyszerek állnak rendelkezésre a megelözés és a gyógyítás terén, az újabb és újabb vírusmutációk megjelenése, valamint a még nem immunizált tömegek miatt napjainkban éppen a járvány negyedik hulláma köszönt Európára.

\section{Központi intézkedések és kommunikáció}

A járvánnyal kapcsolatos foobb védelmi intézkedések meghozatala, megszervezése és a társadalom tájékoztatása a 2020. január 31-én életre hívott Koronavírusjárvány Elleni Védekezésért Felelős Operatív Törzs feladatává vált. A hatékony kommunikáció és az információátadás érdekében a napi sajtótájékoztatók mellett a kormány 2020 márciusában egy online tájékoztatási felületet is létrehozott (https://koronavirus.gov.hu). A járvány előrehaladtával azonban a sajtótájékoztatók a kezdeti informatív tájékoztatás helyett egyre inkább a hatósági adatközlés felé mozdultak el, s a kétoldalú kommunikáció, az interaktivitás is visszaszorult az újságírók személyes jelenlétének ellehetetlenülésével, az előzetesen írásban elküldött kérdések közötti szubjektív válogatással. A járvánnyal kapcsolatos központi adatközlés igen szerény, s bár bővült a közzétett adatok mennyisége és jellege (pl. a kezdeti időszakban nem voltak megyei bontású adatok), a honlap időközben kormányzati hírportállá lényegült át. Az oldalon ugyan napi ${ }^{1}$ adatok szerepelnek, azonban ezek alapján készült idősoros ábrák, elemzések nem elérhetőek, s a területi bontás is csak az igazolt fertőzöttek összesített számára vonatkozóan me-

2021. június 11-től azonban a hétvégi adatszolgáltatás megszúnt, a péntek szombat-vasárnapi adatokat összesítve közlik hétfőnként. 


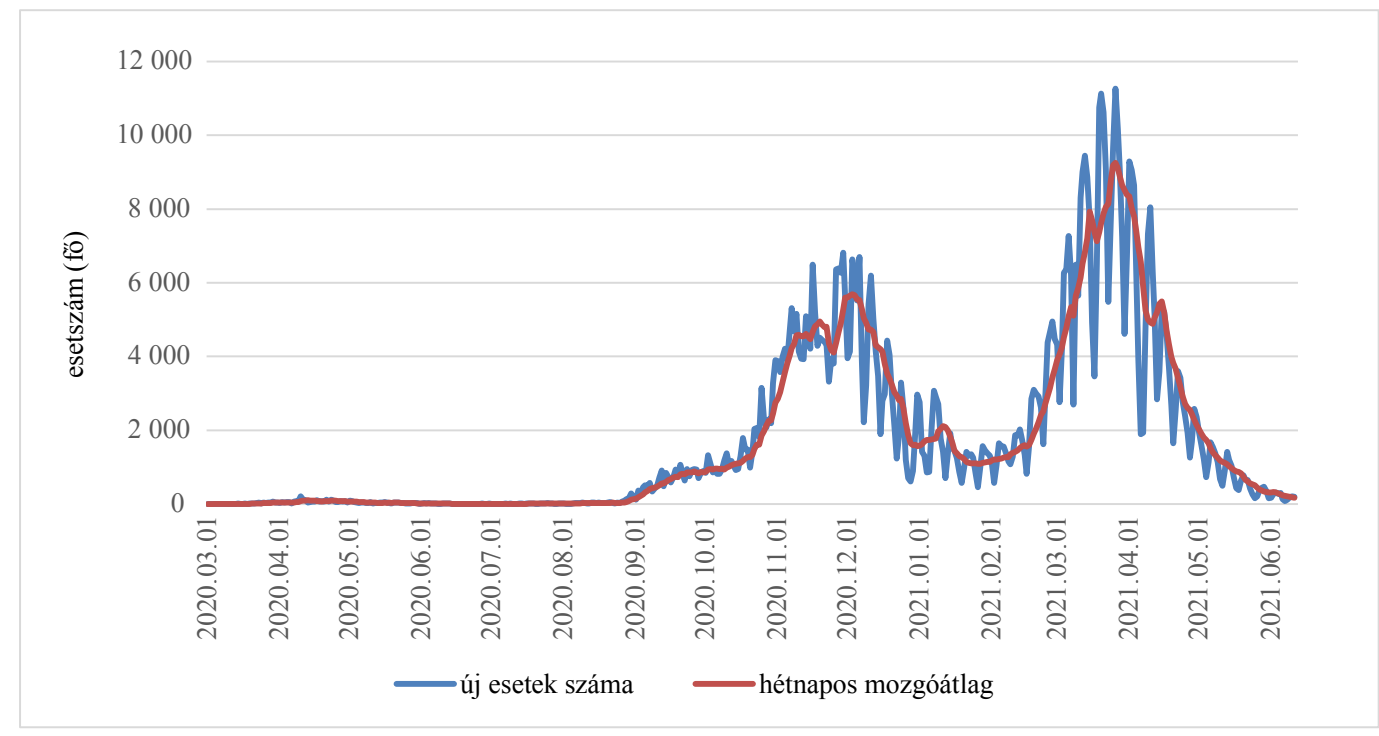

1.ábra

\footnotetext{
A koronavírus-fertőzöttek napi számának alakulása Magyarországon (fő)

Forrás: saját számítás a https://koronavirus.gov.hu oldalon közölt adatok alapján
}

gyei szintû, a többi adatot (aktív fertőzöttek, gyógyultak, elhunytak száma) Budapest-vidék megosztásban közlik. Az ismertetett adatokkal, illetve az adatközlés módjával kapcsolatban számos kritika megfogalmazható, amelyek a tájékoztatáson messze túlmutatva a járványkezelés és az intézkedések iránti társadalmi bizalomra is hatással vannak. Az egyik felmerülő probléma az, hogy sem az aktuális helyzetet, sem a folyamatokat nem lehet a hivatalos oldal adatai alapján értékelni. Nem csoda, hogy számos szakember, internetes lap és blog kezdett el az elérhető adatok alapján különböző ábrák és táblázatok készítésébe, amelyek kielégítik a közvélemény érdeklődő részének igényeit. A területi bontású adatok szükségességével kapcsolatos felvetésekre adott válaszok egy részében az operatív törzs elbagatellizálta a kérdés jelentőségét ${ }^{2}$, egy másik részében pedig adatvédelemre ${ }^{3}$ hivatkozott ${ }^{4}$. Szintén gondot jelent $-\mathrm{s}$ ezt az eredményeink ismertetésénél is hangsúlyozzuk -, hogy a védekezés helyi irányítói, azaz a polgármesterek sem rendelkeztek/rendelkeznek hivatalos forrásból részletes, a településükre vonatkozó adatokkal. Az összesített helyi fertőzöttségi ${ }^{5}$, majd később halálozási ${ }^{6}$ adatokat hosszan

\footnotetext{
${ }^{2}$ „(...) mi tudjuk, hogy hol vannak a fertőzöttek, és őket vizsgáljuk. A járvány lezajlását követően elemzéseket fogunk bizonyára végezni (...)" - Müller Cecí lia országos tisztifőorvos, 2020. 03. 17. https://index.hu/video/ 2020/03/17/koronavirus_operativ_torzs_sajtotajekoztato_elo_kozvetites_ facebook_live/.

3 „(...) változatlanul tiszteletben tartjuk a betegeknek a személyiségi jogait. Én nem hiszem, hogy helyes volna az, hogyha adatok alapján lekövethető volna egy beteg (...)" - Müller Cecília országos tisztifóorvos, 2020. 03. 16. https:// index.hu/video/2020/03/16/koronavirus_operativ_torzs_sajtotajekoztato_ elo_kozvetites_facebook_live/.

${ }^{4}$ Miközben a fertőzésben, illetve a szövődményekben elhalálozottak adatait olyan részletességgel (nem, kor) közlik, hogy - különösen a járvány kezdetén könnyen beazonosíthatóak voltak az elhunytak alapbetegségeikkel együtt.

${ }^{5}$ https://k.blog.hu/2021/02/24/osszesitett_telepulesi_szintu_fertozottsegi_ adatokat kaptunk_muller_ceciliatol

${ }^{6}$ https://k.blog.hu/2021/05/29/covid-telepulesi.
}

elhúzódó adatigénylési folyamat után adta ki az adatgazda Nemzeti Népegészségügyi Központ (NNK), amely korábban azzal védekezett, hogy nem állnak rendelkezésére települési részletezettségú adatok. 2021 júniusában a Miniszterelnökség tette közzé ${ }^{7}$ a beoltottak megyei megoszlását; az adatok létét korábban az NNK szintén tagadta ${ }^{8}$. A fenti példák rámutatnak a központi kommunikációval kapcsolatos fó problémára, arra, hogy feltehetôen az adatok - ismeretlen okból történő - közzé nem tétele és a nyilvánvaló valótlanságok (mert vajon milyen forrásból származhatna egy megyei adat, ha nem helyi adatok összesítéséből??) hatására (is) a társadalom egy jelentős része elvesztette a bizalmát, s kételkedik a közzétett adatok hitelességében?

\section{A belyi önkormányzatok a járványban}

A helyi önkormányzatok rendszerváltáskor meghatározott feladat- és hatásköre fokozatosan csökkent, de a leglényegesebb változások a helyi önkormányzatokról szóló (2011. évi CLXXXIX.) törvény elfogadása óta tapasztalhatók (Oláh 2020). A jogszabály modellváltást eredményezett a területi kormányzásban, minthogy a korábbi önkormányzat-központúság helyébe a centralizált (dekoncentrált), „helyi állam” modellje lépett. A változás egyik fó eleme, hogy az önkormányzatok már nem elsődleges és nem széles felelősségű szervek a helyi köz-

${ }^{7}$ https:/ /444.hu/2021/07/13/budapesten-60-szazalekos-az-oltottsag-borsodban-es-szolnok-megyeben-nem-eri-el-az-50-et.

${ }^{8}$ https://444.hu/2021/06/20/muller-cecilia-nem-tudja-hany-embert-oltot tak-be-az-orszag-kulonbozo-pontjain

${ }^{9}$ Erre vonatkozóan lásd az Ipsos közvélemény-kutatási eredményét (https:// www.ipsos.com/hu-hu/covid-19-visszatekintes-media-felulirta-tenyadatokat), valamint a kormányzati koronavírus-honlap Facebook-oldalának kommentszekcióját (https://www.facebook.com/koronavirus.gov.hu). 
ügyek vonatkozásában, s elvesztették rendelkezési jogukat például az oktatás, a kórházi és egészségügyi szakellátás, valamint részben a szociális gondoskodás felett. A helyi társadalomnak már nincs lehetősége a fenti fontos területek ellenőrzésére, ami az önkormányzatokkal való kommunikáció színtereinek leszúküléséhez, negatív következményként pedig információ- és bizalomhiányhoz vezet (Pálné Kovács 2016).

Az alapvetően a központosított modell felé elmozdult önkormányzati rendszert a járványhelyzet és az ahhoz kapcsolódó gazdasági válság a centralizációs trendek további erősödésével sújtja, ami várhatóan tartós nyomokat hagy a magyar jogrendszeren. Válsághelyzetekben a központosító törekvések jellemzően előnyt élveznek a decentralizációval szemben (Balázs-Hoffman-Hungler 2021), s bár az önkormányzatok feladat- és hatáskörei némileg bővültek a járvány során, mégis a centralizációs elemek dominálnak a hazai szabályozásban.

A katasztrófavédelemről és a hozzá kapcsolódó egyes törvények módosításáról szóló (2011. évi CXXVIII.) törvény 46 . $\$(4)$ bekezdése értelmében a települési polgármesterek a veszélyhelyzet időszakában különleges felhatalmazást kaptak, s néhány kivételtől eltekintve gyakorolhatták a képviselő-testület valamennyi feladat- és hatáskörét (Bubori-Fekete 2020). Az önkormányzat nevében alkotott rendeletek azonban a veszélyhelyzet megszűnésével sem vesztették hatályukat (BalázsHoffman-Hungler 2021). A települések hatáskörébe kerültek az idősek és a hatósági házi karanténban lévők ellátásával összefüggő feladatok, s a húsvéti, valamint azt követő hétvégéken a polgármesterek az országosnál szigorúbb kijárási szabályokat alkothattak, egyénileg szabályozhatták a piacok nyitvatartását, az idősek esetleges vásárlási idősávját, a járvány második hullámában pedig a tízezer fó feletti településeken dönthettek a kötelező maszkviselés területi lehatárolásáról. A fentiek a hatáskörök decentralizációjára szolgáltatnak példát, ugyanakkor az is egyértelmú, hogy ezek azok a kérdések, amelyek bár a helyi viszonyok ismeretét is megkövetelik - népszerütlenebbek, és ellentmondásosságuknál fogva konfliktusokat okozhatnak a helyi társadalomban, ekképpen a felelősség áthárításaként is értelmezhetők (BalázsHoffman-Hungler 2021).

A helyi védekezés megszervezése és irányítása mellett a központi járványkezeléshez való hozzájárulás az önkormányzatok bevételeinek jelentős csökkenését eredményezte. A 92/2020. kormányrendelettel létrehozott Járvány Elleni Védekezési Alap, Gazdaságvédelmi Alap és Európai Unióból Érkező Járvány Elleni Támogatások Alapja forrásait a közös teherviselés jegyében számos pénzösszeg elvonásával, átcsoportosításával biztosították. A helyi önkormányzatoktól elvonták a gépjármúadó eddig települési szinten maradó 40 százalékát, 2020 végéig felfüggesztették az idegenforgalmi adó fizetésének kötelezettségét, időszakosan elengedték a parkolási és közterület-használati díjakat (Balázs-Hoffman 2020; Kovács 2020b; Uzzoli et al. 2021). Az egyes települések büdzséjébe befizetendő iparüzési adó összegének csökkenése a gazdaság visszaesésével borítékolható volt, a gazdaságvédelmi akcióterv (2020. december) azonban a kkv-k és az egyéni vállalkozók adóját hivatalosan a felére csökkentette $^{10}$. Más jellegű, de szintén egyes önkormányzatok bevételeit csökkenti a különleges gazdasági övezetek létrehozása ${ }^{11}$, ami a szabályozási és adóztatási jogköröket a helyi önkormányzatoktól a megyei önkormányzatokhoz irányítja át (Kovács 2020b). A különleges gazdasági övezetről szóló (2020. évi LIX.) törvénnyel a kormányrendeletekben foglaltak a rendes - azaz nem csak a veszélyhelyzeti - jogrendszer részévé váltak, „ami azt a látszatot kelti, mintha a veszélyhelyzeti gazdaságvédelmi indok csupán aktuálpolitikai indok egy újabb, az önkormányzatiságot érintő centralizációra”, még úgy is, hogy a decentralizáció nem, legfeljebb a szubszidiaritás elve sérült (Balázs-Hoffman-Hungler 2021: 30). Miközben a bevételkiesés eltérő súllyal ugyan, de valamenynyi települést érintette, a járványügyi védekezés és a megnövekedett, sok esetben ismeretlen feladatok a költségvetések kiadási oldalán is jelentkeztek, amire a büdzsék átcsoportosításával, dolgozóik intézmények közötti áthelyezésével, önkéntes munkával reagáltak a helyi önkormányzatok (Kovács 2020b).

\section{A kutatás módszere}

Vizsgálatunk célja az volt, hogy áttekintsük a helyi önkormányzatok és a helyi társadalom közötti online kommunikációt a települési honlapokon és Facebook-oldalakon, valamint a polgármesterek közösségi oldalain keresztül. Az elemzés során végigkövettük a járvány eddigi hullámait, három időintervallumban megvizsgálva a tájékoztatási csatornákon közzétett tartalmakat: 2020. március 4. és április 30. között („első hullám”) végeztük az első megfigyelést, s ezt később kiegészítettük egy 2020. novemberi („második hullám”) és 2021. márciusi ( „harmadik hullám”) áttekintéssel. E két utóbbi egy hónapos vizsgálat lehetôvé tette, hogy a járványügyi kommunikáció változásait is értékelhessük.

A vizsgálatba összesen 54 települést vontunk be, ebból 10 megyei jogú város, 19 város (13 járási jogú, 6 egyéb város) és 25 község. Az elemzésünkben szereplő települések körét két korábbi széles körü vizsgálat adta ${ }^{12}$.

\footnotetext{
${ }^{10}$ Kompenzációként a 25 ezer lakosnál kisebb települések a kormánytól támogatást kapnak, a nagyobb önkormányzatok pénzügyi helyzetét pedig majd egyenként tekintik át.

${ }^{11}$ A veszélyhelyzettel összefüggésben a nemzetgazdaság stabilitásának érdekében szükséges intézkedésekről szóló (135/2020.) kormányrendelet alapján különleges gazdasági övezet létrehozható azon a területen, amely nemzetgazdasági szempontból kiemelt jelentőségű beruházásnak minősül, legalább 100 milliárd forint teljes költségigényü, a megye területének jelentős részére kiható gazdasági jelentőségú, s munkahelyek tömeges elvesztésének elkerülését, új beruházás vagy bővítés megvalósítását szolgálja.

${ }^{12}$ A „Helyi közszolgáltatások versenyképességet szolgáló modernizálása” ÁROP 1.1.22-2012-2012-001 projekt, illetve A helyi közszolgáltatások feladatellátás szervezési megoldásai KÖFOP-2.3.3-VEKOP-16-2016-00001 azonosító jelű „Helyi versenyképesség-fejlesztési kutatási program” címú kiemelt projekt.
} 
A városok és községek kiválasztása komplex kritériumrendszer alapján történt: a település jogállása, a település nagysága, földrajzi elhelyezkedése, településhálózati pozíciója, s hogy közös polgármesteri hivatal székhelye-e. A korábbi minta kialakítására a magyarországi településállomány struktúrája miatt a többszintű rétegzés módszerével került sor ${ }^{13}$. Az akkor kiválasztott 50 települést tartalmazó minta kb. 1,6\%-os kiválasztási arányt jelentett, ami az információk kvalitatív jellegú feldolgozása miatt elfogadható. Jelen tanulmány készítése során kénytelenek voltunk néhány cserére, de ezekben az esetekben mindig igyekeztünk hasonló adottságokkal rendelkező településeket bevenni a mintába.

Vizsgálati módszerként tartalomelemzést végeztünk. A tudományos igényü tartalomelemzést ma már számos tudományterület alkalmazza a szociológiától kezdve a pszichológián, politológián keresztül az irodalom- és történelemtudományig (Kérdő 2008). A tartalomelemzés a társadalomtudományok fontos beavatkozás-nélküli kutatási módszere, mely a kommunikáció manifeszt tartalmának objektív, szisztematikus és kvantitatív eszközökkel való leírására szolgál (Berelson 1952), ugyanakkor fejlődése során kialakult egy kvalitatív irány is, amely nem numerikus és mennyiségi szempontokra helyezi a hangsúlyt, hanem a közlések, szövegek látens, szemantikai tartalmának megfejtésére és az azokból levonható következtetésekre összpontosít (Kérdó 2008). A tartalomelemzést napjainkban online kommunikáció vizsgálatára is gyakran alkalmazzák; a közösségi média elemzését végző kutatásokról a 2007 és 2013 között megjelent szakirodalmak alapján megállapítást nyert, hogy e kutatások során a tartalomelemzés volt a második leggyakrabban alkalmazott módszer (Snelson 2016). A kutatók elsősorban Facebook-bejegyzéseket, tweeteket (Twitter-bejegyzéseket), YouTube-videókat vagy más közösségimédiatartalmat használnak adatforrásként, és a legkülönbözőbb területekre fókuszálnak (lásd pl. részletesebben Snelson 2016). Ugyanakkor a webalapú tartalomra alkalmazott tartalomelemzésnek is vannak technikai és egyéb korlátai (Kim-Kuljis 2010). Hátrányként merülhet fel a weboldalak változása, melynek következtében a feldolgozott információk elvesznek, eltünnek az online térből, s további korlátként merül fel a weboldalakhoz való egyenlótlen hozzáférés (Thomas-Tunney 2019), hiszen vannak olyan társadalmi csoportok, melyek nem, vagy korlátozottan férnek hozzá az online információkhoz és a webes felületekhez az IKT-eszközök vagy azok használatához szükséges tudások, készségek hiánya miatt, így kimaradnak az online kommunikációból.

A tartalomelemzés során részben követtük a Neuendorf (2002) által javasolt, kilenc fázisból álló folyamatot, melynek első lépése a kutatási kérdések és/vagy hipoté-

\footnotetext{
${ }^{13}$ A kiválasztás részletesebb leírását és a települések listáját lásd HBH Stratégia és Fejlesztés Kft. \& Collective-Intelligence Kft. 2018: 30-37.
}

zisek megfogalmazása, az utolsó pedig az adatok elemzése és értelmezése, megállapítások megfogalmazása.

Az általunk végzett tartalomelemzés fó szempontjai, illetve fázisai az alábbiak voltak:

- Információközlés helyének és módjának meghatározása: a kiválasztott településeken a kommunikációra használt online felületek beazonosítása - települési honlapok, települések, polgármesterek Facebook-oldala. Az önkormányzatok a közösségimédia-platformok közül elsősorban a Facebookot használják, ami racionális választásnak tûnik, hiszen ezt általánosan elterjedt és a felnőtt felhasználók meghatározó közösségi médiaplatformjaként definiálják (Duggan et al. 2015).

- Mintavétel: az említett három platformtípuson megjelenő hírek, információk teljes körü elemzését végeztük el, ugyanakkor időbeli szúkítéssel éltünk.

- Koronavírus-járvánnyal kapcsolatosan kommunikált tartalmak, információk, hírek gyújtése: a jelölt három időszakban mindhárom platformon minden olyan információ, hír, intézkedés stb. összegyújtése, ami a koronavírus-járvánnyal kapcsolatban megjelent. Az információk összegyưjtését 'kézi vezérléssel' végeztük, nem használtunk szoftveres segítséget a legyújtéshez.

- Koronavírus-járvánnyal kapcsolatos információk megjelenítésének mikéntje: egyáltalán vannak-e ilyen információk a települések honlapján, milyen az információk 'láthatósága', hogyan jelenítik meg azokat. Azokban az esetekben, amikor a település honlapjának nyitóoldalán semmi sem utalt a COVID-19 járványhelyzetre, kulcsszavas keresést alkalmaztunk (koronavírus, járvány/járványhelyzet, COVID-19, humánjárvány).

- Gyakoriságelemzés: információmegosztás gyakorisága - információk mennyisége és a megosztás, közzététel rendszeressége.

- Információk jellegzetességeinek leírása: közölt információk tematikája, témák beazonosítása - milyen információkat közölnek, osztanak meg. Jellemző kategóriák: alapinformációk a járvánnyal kapcsolatban, helyi járványügyi adatok; helyi információk és intézkedések; országos információk és intézkedések; önkéntesek és adományok; más típusú médiaeszközök kapcsolása.

- A kommunikáció stílusa, hangneme és a megjelenített értékelemek: mennyire objektív, hivatalos vagy személyes a hangvétel, érzelmekkel átitatott vagy esetleg politikai töltetű a közölt tartalom, milyen értékeket közvetít (pl. szolidaritás, fegyelmezettség).

- Üzenetek hatásai: e téren elsődlegesen az interaktivitásra (visszacsatolásra) való lehetőséget, illetve a lakossági észrevételekre való reagálást vizsgáltuk.

\section{A kutatás eredményei}

Elemzésünket egy szélesebb körü kutatás részeként végeztük, melynek során a helyi önkormányzatokat kerestük meg, fókuszban a járvány helyi jellemzőinek, intéz- 
kedéseinek és nehézségeinek a feltárása volt (a kutatás eredményeiről bővebben Finta-Kovács-Pálné Kovács 2020a; Pálné Kovács 2020). Jelen tanulmány szerzői e kutatás keretén belül az önkormányzati kommunikációt vizsgálták. Bár a járvány idején szinte az összes helyi önkormányzat használta az internetet a lakosok tájékoztatása és a velük való kommunikáció érdekében, sok helyütt a helyi média (helyi újság, tv) és a hagyományos, papíralapú csatornák (pl. szórólapok) is elengedhetetlenek voltak annak érdekében, hogy a lakosság teljes körét (pl. idóseket is) elérjék. Tapasztalatok szerint az 50 év alatti korosztály nagyon aktív volt az online felületeken, viszont az idősebb generáció igényelte az online felületeken kívüli tájékoztatást is, méghozzá a korábbinál gyorsabb és rugalmasabb formában.

Az elemzésünkbe bevont összes önkormányzat folytatott online kommunikációt, használta a település honlapját vagy Facebook-oldalát, illetve a polgármester Facebook-oldalát a járványhelyzettel kapcsolatos információk megosztására. A település nagyságától függetlenül számos helyi önkormányzat külön füleket vagy aloldalakat különített el honlapján a járványról való tájékoztatás érdekében, így a járványhoz kapcsolódó információk könnyebben áttekinthetőek. Ugyanakkor arra is találunk példát, hogy a település honlapjának nyitóoldalán semmiféle jelét nem találjuk a rendkívüli helyzetnek, és csak külön kulcsszavas kereséssel lehet a koronavírus-járvánnyal kapcsolatos információkat találni.
Néhány önkormányzat kivételével a COVID-19-cel kapcsolatos első információk mindenhol március első felében jelentek meg. A járvány kezdetén az információk többnyire gyakoribbak voltak, a legtöbb településen naponta több hírt és információt osztottak meg. Általánosságban azonban a járvány előrehaladtával csökkent a közölt információk mennyisége (2. ábra) és a közlés gyakorisága is, illetve egyre több helyen egyértelmúen a Facebook vált az online kommunikáció fő csatornájává. A második és a harmadik hullámban még inkább visszaesett a kommunikációs aktivitás (2. ábra), a városokban mindenhol jelentek meg hírek, de ritkábban és kevesebb, a falvak körében azonban több olyan önkormányzatot is találunk (a vizsgált önkormányzatok körében a második hullám alatt 5, míg a harmadik hullám alatt már 12), amelyek nem használták az online felületeket hír- és információközlésre, -megosztásra. A legtöbb városban a kommunikációs aktivitás a második hullámban jelentősen visszaesett, a napi hírek általában elmaradtak ott is, ahol az információmegosztás az első időszakban nagyon gyakori volt. Összességében a rendelkezésre álló információk mennyisége és köre széles skálán mozgott, a nagyon kicsi/szúk tartománytól kezdve az információdömpingig minden előfordult.

A legtöbb település esetében a legelső információk vagy az egyes intézmények megváltozott látogatási szabályaival, vagy különböző események, rendezvények elmaradásával kapcsolatos tájékoztatást jelent. Ezzel pár-

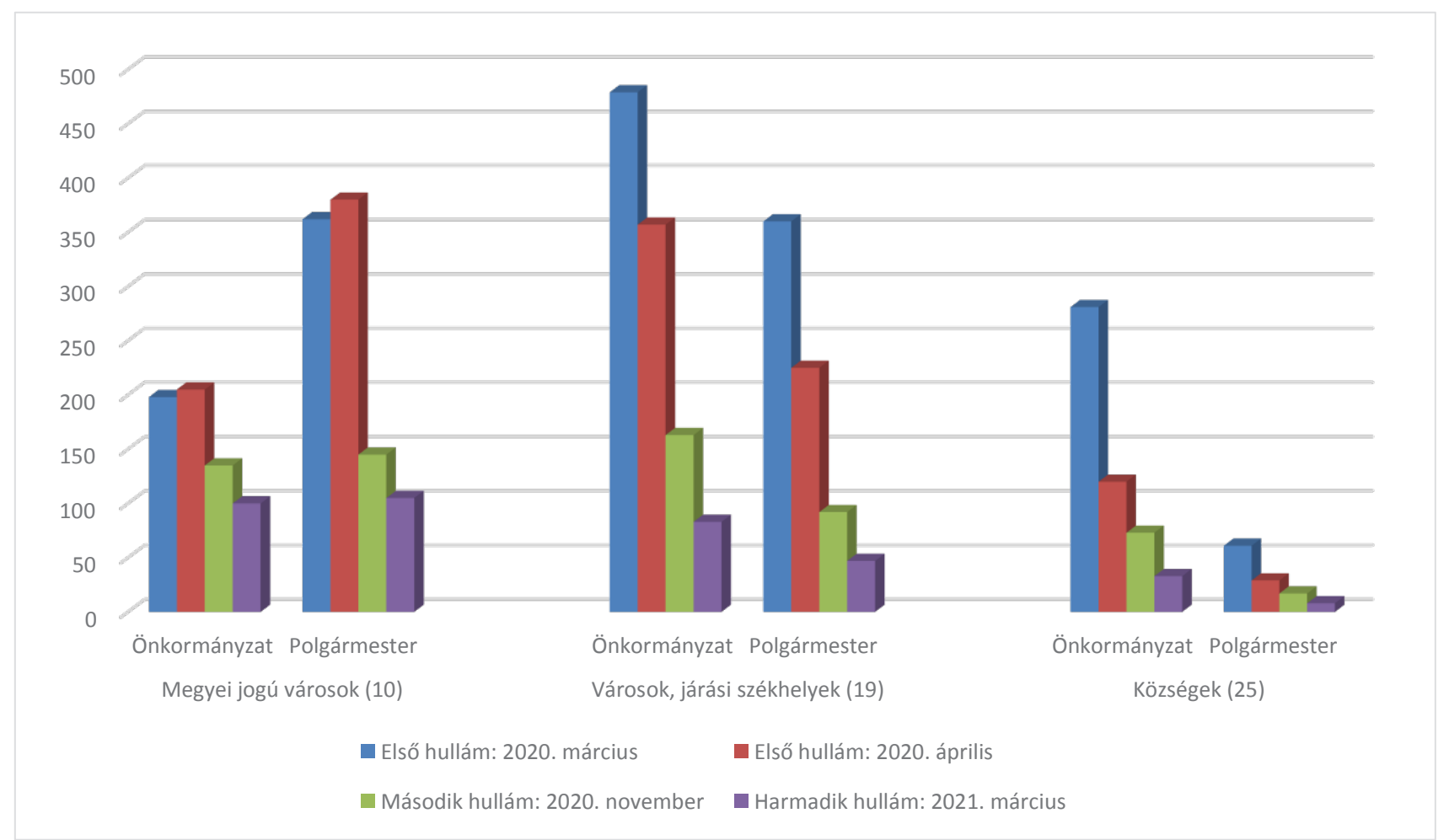


huzamosan általában a koronavírusra vonatkozó tudnivalók, alapinformációk (pl. helyes kézmosás, a koronavírus-fertőzés tünetei, teendők, a lehetséges óvintézkedések és viselkedés) jelentek meg a járványhelyzettel kapcsolatos kezdeti helyi online kommunikációban. Ezek az első hírek általában tartalmazták az országos tájékozódási felületek elérhetőségeit is (pl. zöld számok, webcímek: www.koronavirus.gov.hu; www.nnk.gov.hu) és a helyi elérhetőségeket is (telefonszámok, e-mail-címek). Eleinte a helyi önkormányzatok általában országos híreket és rendeleteket tettek közzé (pl. veszélyhelyzetet hirdető kormányrendelet, korlátozó intézkedések), később a helyi információk váltak inkább dominánssá.

Mint fentebb említettük, még a járványügyi intézkedéseket és feladatokat ellátó helyi önkormányzatokat sem tájékoztatták hivatalosan a helyi adatokról. Az első időszakban, amikor még a megyei adatok sem voltak nyilvánosak, a polgármesterek különösen nehéz helyzetben voltak az információhiány miatt. Ennek megfelelően az első hullám idején szinte semmilyen helyi járványügyi adat nem jelent meg sem az önkormányzatok honlapján, sem a Facebook-oldalakon, bár sok önkormányzat polgármestere a rendelkezésükre álló információk alapján tájékoztatta a lakosságot, így például a hatósági és/vagy önkéntes karanténban tartózkodók számáról, illetve arról, hogy van-e tudomásuk fertőzöttről a településen. A második és a harmadik hullám során több helyen jelennek meg időről időre, igaz, nem rendszeresen, helyi járványügyi adatok. A jelenség független a település nagyságától; inkább a polgármester kapcsolati hálójától (társadalmi tókéjétól) és elkötelezettségétől függ, hogy hozzáfér-e a helyi adatokhoz. Azon adatokat, melyeket a központi kommunikáció a helyi intézmények szintjén nyilvánvalóvá tett (például az oktatási vagy szociális intézményekben végzett központi tesztek eredményeit, a fertőzések vagy fertőzések gyanúja miatt történt intézményi bezárásokat), a lakosság tájékoztatása érdekében a helyi önkormányzatok jelentős része közzétette az online felületeken.

A települési önkormányzatok rendszeresen tájékoztatták a lakosságot a települést érintő, az országostól eltérő intézkedésekről. Ezen intézkedések tartalma értelemszerúen változott az egyes hullámok során. Általában a szükséges információk, például a település járványügyi helyzetére vonatkozó adatok nélkül kellett a polgármestereknek a döntéseket meghozniuk. Az első hullám során voltak olyan önkormányzatok, amelyek a vásárlási időkorláton vagy a piac bezárásán kívül nem érvényesítettek semmilyen más korlátozást sem. A legtöbb település viszont bezárta játszótereit és szabadtéri sportpályáit is. Sok helyütt egyéb korlátozásokat vezettek be a hétvégén; turisztikai vagy természeti jelentőségű településeken a lakosság védelme érdekében a terület egészének vagy egy részének bezárásáról döntöttek. Az éjszakai kijárási tilalom bevezetésével Kecskemét városa volt a legszigorúbb.
A központi szabályozásnak megfelelően a második hullám során a 10000 lakosnál nagyobb városokban bevezették a maszkok használatát a közterületeken. A települések maguk dönthették el, hogy hol írják elő a maszkhasználatot (volt olyan város, ahol csak a piacok és vásárok területén vagy a buszmegállókban kellett viselni). A legtöbb város azonban kötelezővé tette a maszkok használatát a város összes nyilvános területén. Egyes kisebb városok körében jellemző volt, hogy lehatárolták a település egy részét (jellemzően a Belvárost, belső utcákat), ahol a közterületen viselni kellett a maszkot, illetve a közintézmények, irodák, üzletek (esetleg társasházak) közelében (általában 50 méteren belül), parkolókban, buszmegállókban, vasúti peronokon. A harmadik hullám során a helyi önkormányzatoknak nem volt ilyen mérlegelési lehetőségük, mivel a maszk használata kormányrendelet alapján kötelezővé vált minden település valamennyi közterületén.

Bár a helyi önkormányzatok csak részben dönthettek a helyi intézmények bezárásáról, a róluk szóló hírek általában a nyilvános információk részét képezték. A kistelepülések kommunikációjában - mivel kevesebb az intézmény, de gyakran az egész közösséget szolgálják - hangsúlyosabbak voltak a polgármester által elrendelt rendkívüli szünetek, az intézmények bezárása fertőzések vagy fertőzés gyanúja miatt. Az információszolgáltatásban gyakori volt a polgármesteri hivatal, illetve más közintézmények megváltozott ügyfélfogadási rendjének kommunikálása. Ugyanakkor meglepő módon nem minden nagyobb városban jelezték az önkormányzat, a háziorvosok és más fontos közintézmények elérhetőségeit a vizsgált online felületeken, a kisebb települések többsége azonban még a járvány kezdetén közzétette ezeket.

Mivel a járvány kezdetén a helyi önkormányzatok feladatai hirtelen megnövekedtek, számos szolgáltatást - pl. idősek védelme érdekében számukra a bevásárlás vagy gyógyszerek kiváltása - meg vagy át kellett szervezni, sok településen önkénteseket toboroztak, melyre az online felületek kiváló lehetőséget szolgáltattak. A településeken önkéntesekre, a helyi intézmények alkalmazottaira és a civil szervezetek tagjaira is szükség volt a hatékony védekezéshez, az önkéntesek varrtak arcmaszkokat, amelyek az első hullám idején még hiányoztak, fertőtlenítették az intézményeket és a közterületeket, segítették az otthonukban élő idős emberek vagy fogyatékossággal élők ellátását. A második és a harmadik hullámban alig akad olyan település, ahol önkénteseket toboroztak volna az önkormányzatok a közösségi média segítségével, egyes helyeken az önkormányzatok/polgármesterek véradást és plazmaadományt szorgalmaztak.

Számos önkormányzat a korábban említett adólevonások és egyéb kieső bevételek pótlására védelmi alapot, adománygyưjtő számlát hozott létre, vagy alszámlát különített el, ezekről és egyéb adományozási lehetőségekről - többen a gyưjtés eredményéről is - tájékoztatták a lakosságot és a település egyéb aktorait a honlapon és a Facebookon is. 
A járvány miatt nehéz helyzetbe került vállalkozások és lakosok (pl. akik elvesztették az állásukat) megsegítésére számos önkormányzat helyi intézkedéseket, akciókat, támogatási programokat hozott létre. Az online meghirdetett intézkedések közül meg kell említenünk Veszprémet, ahol a vendéglátóipari cégekkel egyeztetve vissza nem térítendő támogatás formájában pályázatot írtak ki rájuk. Győrben a bezárni kényszerülő vállalkozások számára eltörölték az állami és önkormányzati tulajdonú ingatlanok bérleti díját. Szolnok helyi intézkedésekkel segítette a taxisokat. Kisebb városokban találunk példát arra, hogy az önkormányzat a helyi éttermek élelmiszer-szállítási adatait teszi közzé a weboldalán és/vagy a Facebook-oldalán. Vannak helyek, ahol az első hullám során, a piac bezárása után az önkormányzat információk megosztásával támogatta az online piac megszervezését, és ingyenes lehetőséget biztosított a helyi vállalkozások bemutatkozására az online felületein.

A kistelepülések körében is jellemző, hogy egy részük anyagi támogatást és szociális segítséget nyújtott a nehéz helyzetbe került vállalkozásoknak, lakosoknak. Volt, ahol az állandó lakosok egyszeri juttatást kaptak 2020 novemberében, vagy ahol a második hullám alatt nyújtott az önkormányzat pénzügyi támogatást azoknak a lakosoknak, akik a járványhelyzet miatt elveszítették munkájukat és nem voltak jogosultak munkanélküli ellátásra, míg másutt a korlátozások által érintett vállalkozásokat segítették szolgáltatásaik online népszerüsítésében. Az első hullám során a közösség problémáinak enyhítése érdekében néhány kis önkormányzat úgy döntött, hogy megváltoztatja a helyi adók befizetésének folyamatát és határidejét, és több helyen anyagilag vagy eszközökkel járultak hozzá a digitális oktatás feltételeinek javításához.

A harmadik hullám során, amikor az oltás már rendelkezésre állt, több önkormányzat segítséget kínált a lakosok számára az oltásra való regisztrációban. Ebben az időszakban sok településen - fóleg a városokban - egyre nagyobb hangsúlyt fektettek az oltás szükségességének és a regisztráció fontosságának hangsúlyozására.

Az információközlés mikéntjét tekintve elmondható, hogy foóként a városokban nemcsak az információk és intézkedések írásos közzététele volt a jellemző, hanem polgármesteri videóüzenetek, videófelvételek készítése, vagy a helyi médiát bevonó polgármesteri tájékoztatók és riportok készítése és továbbítása is. Volt, ahol külön járványügyi információs programot/músort indítottak, amely a rendszeres jelentések mellett néhány városban (pl. Pécs) interaktivitást is biztosított. Ezt a jó gyakorlatot több város is átvette a második (majd a harmadik) hullám során, de kisebb településeken ritkán találunk példát erre az információformára. A kommunikáció szempontjából nagyon fontos lenne a kétoldalúság, a visszacsatolás, interaktivitás lehetősége, hogy legyen lehetőség kérdéseket feltenni, panaszokat jelezni, javaslatokat tenni. A települések honlapján erre nagyon ritkán van lehetőség, csak néhány városban nyílt erre mód, ugyanakkor a Facebook jellege magában hordozza az in- teraktivitás lehetőségét. Ugyanakkor tapasztalataink azt mutatják, hogy az érdeklődés szintjétől függetlenül csak néhány esetben érkeztek érdemi válaszok a város vezetőitől vagy az önkormányzat egyéb szereplőitől a lakossági kérdésekre és aggodalmakra. Kistelepüléseken, ahol a lakosok általában személyesen ismerik egymást, így a polgármestert is, a járványidőszakban folytatott online kommunikáció kevésbé volt formalizált, az önkormányzat vagy a vezetók nagyobb valószínúséggel reagáltak a nyilvános megjegyzésekre. A tapasztalatok azt mutatják, hogy az önkormányzatok nem használják ki a közösségi médiában rejlő lehetőségeket, hiszen elsődlegesen egyirányú kommunikációra, azaz csupán tájékoztatásra szorítkoznak ahelyett, hogy aktívan bevonnák a polgárokat egy partneri kétirányú kommunikációba.

A világjárvány első időszakában a szolidaritás, az együttmúködés, a segítségnyújtás és a fegyelem hangsúlyozása, a szabályok betartása, az állampolgárok felelős magatartása, a harmadik hullámban a türelem és a kitartás sok helyen fontos eleme volt a tájékoztatásoknak. A polgármesteri tájékoztatók szinte mindegyikében az első perctől fogva meghatározó volt a köszönetnyilvánítás, illetve az otthon maradásra (elsősorban az első hullám során) és a maszk viselésére (inkább a második és a harmadik hullám alatt) való felszólítás is. A polgármesterek kisebb hányadának kommunikációjában erős érzelmi töltet is érződik, de a tájékoztatások általában hivatalos hangvételüek, a polgármesterek Facebook-oldalain is. A hírek csupán elenyésző hányadának és nagyon kevés helyen volt politikai töltete (pl. az elvont gépjárműadó és elvont idegenforgalmi adó, illetve a kórházi ágyfelszabadítás miatt hazaküldött betegek kapcsán), de ez a második és a harmadik időszakra gyakorlatilag teljesen eltünt. Tulajdonképpen néhány kivételtől eltekintve viszonylag kevés felháborodás és kritika hangzik el a kormányzati és járványkezelési kérdésekkel kapcsolatban a helyi kormányzati kommunikációban. A pandémia által generált krízishelyzetben egyértelmúen a helyi szintû együttmúködés, összefogás hangsúlyozása került előtérbe.

\section{Következtetések}

A COVID-19 járványban a helyi önkormányzatok hatalmas nyomás alá kerültek. A változó járványhelyzet és a gyors reagálás szükségessége felhívta a figyelmet az önkormányzatok és a lakosok közötti kommunikáció fontosságára, valamint az új kommunikációs csatornák használatára. Láthatóan az emberekben óriási igény volt a járványhelyzet alatt a hiteles és naprakész tájékoztatásra, a döntések indoklására, amit a települések jelentős részében lehetőségeikhez mérten meg is tettek. A helyi politikai hatalom szereplői éltek az online fórumok és a helyi média adta lehetőségekkel. Ugyanakkor az embereknek nagy igényük volt a párbeszédre is, kevés kivételtől eltekintve azonban nem fektettek hangsúlyt az önkormányzatok a helyi igények, vélemények felmérésére, nem használták ki az IKT-eszközök és -technológiák adta ez 
irányú lehetőségeket. Pedig a kétirányú kommunikáció ismérve a jó kormányzásnak, partneri viszonyt teremt, növeli a helyi politikai hatalom legitimációját, fokozza a lakosság aktivitását, együttmúködési hajlandóságát, ezáltal hozzájárul a sikeres problémakezeléshez, sőt elengedhetetlennek tünik hozzá.

Természetesen az intézkedések és a nyilvánossággal való kapcsolattartás teljes skálája nem értékelhető a helyi önkormányzatok online kommunikációjából, de elmondható, hogy az információk közzététele tematikusan változott, és a járvány első hónapja óta jelentősen csökkent mennyiségében és gyakoriságában. Voltak olyan önkormányzatok, amelyek kiválóan teljesítettek az online kommunikációban, azaz rendszeres és releváns információkat tettek közzé, de voltak olyanok is (fóként kistelepülések), amelyek egyáltalán nem, vagy egy idő után nem használták ezeket a csatornákat. Ez utóbbi azzal magyarázható, hogy a település lakossága - korösszetétele vagy az internethasználat jellemzői miatt - fóleg más, hagyományos csatornákon keresztül hatékonyan tájékoztatható. Az online kommunikáció „kiküszöbölése” azzal is magyarázható, hogy más csatornák hatékonynak bizonyultak, és az önkormányzat ehhez alkalmazkodott. Aligha kétséges, hogy a helyi önkormányzatok rendelkezésére álló információk hiánya, a helyi szerepvállalás csökkenése és a járványkezelés terén egyre növekvő központi irányítás a helyi szintű kommunikációt is háttérbe szorította. Ráadásul a lakossághoz hasonlóan a helyi önkormányzatok többsége belefáradt a több mint egy éve tartó járványba, amely szintén hozzájárulhat az online aktivitás csökkenéséhez.

Az információhiány, amely a kezdeti időszakban különösen jellemző volt, de igazából fennmaradt a második és harmadik hullám során is, lehetetlen helyzetbe hozta a helyi önkormányzatokat; intézkedéseket csak a közvélemény által elfogadott és betartható hiteles információk alapján lehet megtenni, és ez esetben ez nem könnyú feladat. A központosított járványkezelés és kommunikáció Magyarországon inkább meggyengítette, mint megerôsítette a bizalmat, ami válsághelyzetekben elengedhetetlen.

\section{Irodalomjegyzék}

American Red Cross (2012) Social Media in Disasters and Emergencies. The American Red Cross. https://www.google.hu/url? sa=t $\& r c t=j \& q=\& e s r c=s \&$ source $=$ web \&cd $=\& v e d=2 a h U K E w j V w c-$ r4NH0AhUN3qQKHaAPDgUQFnoECAMQAQ\&url=https\%3 A $\% 2$ F\% 2Fwww.redcross.ca $\% 2$ Fcrc $\% 2$ Fdocuments $\% 2$ FSocialMedia-in-Emergencies-Survey-Oct-2012-English.pdf\&usg= AOvVaw31tOlnc4ghsq8m9J-ggpvp [Letöltve: 2021. 07. 06.]

Bajnok A. (2014) Helyi nyilvánosság(ok) kommunikatív-diszkurzív leírása és értelmezése. Kommunikáció, közösség és kormányzás egy település önállósodásának tükrében. (Doktori disszertáció.) Budapest-Pécs: Pécsi Tudományegyetem

Balázs I. (2021) A közigazgatás rezilienciája, avagy a magyar közigazgatás rezilienciájáról a COVID válság idején. Miskolci Jogi Szemle, Vol. 16. No. 1. pp. 13-22.

Balázs I. \& Hoffmann I. (2020) Közigazgatás koronavírus idején - a közigazgatási jog rezilienciája? MTA Law Working Papers 2020/21. Budapest: Magyar Tudományos Akadémia https://jog.tk.hu/ mtalwp/kozigazgatas-koronavirus-idejen-a-kozigazgatasi-jog-rezilienciaja [Letöltve: 2021. 07.07]

Balázs I., Hoffman I. \& Hungler S. (2021) „Veled Uram, de nélküled” - Állam, önkormányzatok, munkáltatók a koronavírus idején. Magyar Tudomány, Vol. 182. No. 5. pp. 625-634. https://doi. org/10.1556/2065.182.2021.5.6 [Letöltve: 2021. 07. 07.]

Belényesi E. (2011) Önkormányzati marketingkommunikáció - a hazai gyakorlat. Új Magyar Közigazgatás, Vol. 4. No. 11. pp. 30-35.

Bene M. (2019) Virális politika: politikai kommunikáció a Facebookon. (Doktori disszertáció.) Budapest: Budapesti Corvinus Egyetem

Berelson, B. (1952) Content Analysis in Communication Research. New York: Free Press

Bernier, S. (2013) Social Media and Disasters: Best Practices and Lessons Learned. (presentation, American Red Cross Disaster Preparedness Summit, August 21, 2013) https://docplayer. net/14632574-Social-media-and-disasters.html [Letöltve: 2021. 07. 06.]

Bubori N. B. \& Fekete K. B. (2020) Veszélyhelyzetben a polgármester dönt? Jegyző és Közigazgatás, Vol. 22. No. 2. https://jegyzo.hu/ veszelyhelyzetben-a-polgarmester-dont/\#_ftnl] [Letöltve: 2021 . 03. 30.]

Conrado, S. P., Neville, K., Woodworth, S. \& O'Riordan, S. (2016) Managing Social Media Uncertainty to Support the Decision Making Process During Emergencies. Journal of Decision Systems, Vol. 25. No. 1. pp. 171-181. https://doi.org/10.1080/12460125.20 16.1187396 [Letöltve: 2021.07.06.]

Duggan, M., Ellison, N. B., Lampe, C., Lenhart, A. \& Madden, M. (2015) Social media update 2014. Pew Research Center. https:// www.pewresearch.org/internet/2015/01/09/social-media-update-2014/ [Letöltve: 2021.07. 05.]

Fekete K., Dombi G., \& Oláh M. (2021) Önkormányzati válságkezelés a Balaton Kiemelt Üdülókörzetben, a COVID-19-járvány első hullámában. Területi Statisztika, Vol. 61. No. 3. pp. 337-355. https://www.ksh.hu/statszemle_archive/terstat/2021/2021_03/ ts610304.pdf [Letöltve: 2021. 07. 05.]

Finta I., Kovács K. \& Pálné Kovács I. (2020a): Önkormányzatok a koronavírus járvány kezelésében. Tér és Társadalom, Vol. 34. No. 4. pp. 184-198.

Finta I., Kovács K. \& Pálné Kovács, I. (2020b) The Role of Local Governments in Control the Pandemic in Hungary. In: IGU Commission Geography of Governance (2020) Local Government Response Towards Covid-19 Pandemic: a Worldwide Survey and Comparison. https://sites.google.com/view/igucgog-covid19/ working-papers [Letöltve: 2021.03. 30.]

Forray R. K. \& Kozma T. (2021) Közösségi tanulás járvány idején. Educatio, Vol. 30. No. 1. pp. 36-49.

Franzke, J. (2020) German Municipalities in the COVID-19 Pandemic Crisis. Challenges and Adjustments. A preliminary analysis. In: IGU Commission Geography of Governance (2020)

Gertheis A. (2021) A Covid19-járvány hatása a kerékpáros közlekedésre. XXV. Nemzetközi Építéstudományi Konferencia - ÉPKO. pp. 55-59. https://ojs.emt.ro/index.php/EPKO/article/view/546 [Letöltve: 2021.07.05.]

Gore, T., Bimpson, E., Dobson, J. \& Parkes, S. (2021) Local Government Responses to the COVID-19 Pandemic in the UK: A Thematic Review. In: IGU Commission Geography of Governance (2021) Local Government Response Towards Covid-19 Pandemic: a Worldwide Survey and Comparison. https://sites.google.com/ view/igucgog-covid19/working-papers [Letöltve: 2021.07. 05.]

Graham, M. W., Avery, E. J. \& Park, S. (2015) The role of social media in local government crisis communications. Public Relations Review, Vol. 41. No. 3. pp. 386-394. http://dx.doi.org/10.1016/j. pubrev.2015.02.001 [Letöltve: 2021. 07. 07.]

Grünhut Z. \& Bodor Á. (2020) A bizalom kultúrájának próbatétele: A fizikai és lelki egészség, továbbá a társas kapcsolatok és a szubjektív anyagi helyzet összefüggései a bizalommal járványidőszakban. Tér és Társadalom, Vol. 34. No. 3. pp. 26-45. 
HBH Stratégia és Fejlesztés Kft. \& Collective-Intelligence Kft. (2018) Összefoglaló Kutatási Jelentés 2. célterület: A helyi közszolgáltatások feladatellátás-szervezési megoldásai. KÖFOP-2.3.3-VEKOP16-2016-00001 azonosító jelû́ „Helyi versenyképesség-fejlesztési kutatási program” címú kiemelt projekt kapcsán. https://bm-oki. hu/News/ViewFile?fileID=1133 [Letöltve: 2021.03 . 30.]

Hughes, A. L. \& Tapia, A.-H. (2015) Social Media in Crisis: When Professional Responders Meet Digital Volunteers. Journal of Homeland Security and Emergency Management, Vol. 12. No. 3. pp. 679-706. https://www.researchgate.net/publication/ 273914566_Social_Media_in_Crisis_When_Professional_ Responders_Meet_Digital_Volunteers [Letöltve: 2021.07.06.]

Jenei Á. (2010) Időgazdálkodás és önkormányzati kommunikáció. Budapest: Települési Önkormányzatok Országos Szövetsége

Jin, Y., Liu, B. F. \& Austin, L. L. (2014) Examining the Role of Social Media in Effective Crisis Management: The Effects of Crisis Origin, Information Form, and Source on Publics' Crisis Responses. Communication Research, Vol. 41. No. 1. pp. 74-94. https:// journals.sagepub.com/doi/abs/10.1177/0093650211423918 [Letöltve: 2021.07. 06.]

Jóna L. (2020) A COVID-19 járvány hatása a közösségi terek használatára és jövőjére. Tér és Társadalom, Vol. 34. No. 3. pp. 295-306.

Karakiza, M. (2015): The Impact of Social Media in the Public Sector. Procedia - Social and Behavioral Sciences, Vol. 175, pp. 384-392. https://www.researchgate.net/publication/273391147_The_Impact_of_Social_Media_in_the_Public_Sector[Letöltve: 2021. 07. 06.]

Katona M. \& Petrovics N. (2021) Válság és együttmúköóés. A koronavírus-járvány okozta lehetséges intézményi változások és a kooperatív közszolgáltatások. Közgazdasági Szemle, Vol. 68. No. 1. pp. $76-95$

Kérdő A. (2008) A tartalomelemzés elmélete és gyakorlati alkalmazása. Budapest: Budapesti Gazdasági Fóiskola

Kim, I. \&Kuljis, J. (2010) Applying Content Analysis to Web based Content. ITI 2010 32nd Int. Conf. on Information Technology Interfaces, June 21-24, 2010, Cavtat, Croatia. pp. 283-288. https://doi.org/10.2498/cit.1001924 [Letöltve: 2021. 07. 05.]

Koós B. (2020) A koronavírus-járvány társadalmi-területi aspektusai Magyarországon. Tér és Társadalom, Vol. 34. No. 2. pp. 171-177.

Koós B., Kovács S. Zs., Páger B. \& Uzzoli A. (2020) Epilógus: Az új koronavírus-járvány társadalmi-gazdasági hatásai és ezek területi következményei. In: Czirfusz M. (ed.) Területi kihívások és területi politikák Magyarországon, 2010-2020. Budapest: Közgazdaság- és Regionális Tudományi Kutatóközpont Regionális Kutatások Intézete. pp. 123-131. http://www.regscience.hu:8080/xmlui/ handle/11155/2319 [Letöltve: 2021. 07. 07.]

Kovács S. Zs. (2020a) Az alapvető pénzügyi szolgáltatások online térbe helyezésének korlátai. Tér és Társadalom, Vol. 34. No. 2. pp. 195-201.

Kovács S. Zs. (2020b) Települési önkormányzatokat érintő bevételkiesések a járványhelyzetben. Tér és Társadalom, Vol. 34. No. 2. pp 189-194.

Kriskó E. (2012) Az önkormányzati katasztrófakommunikáció webkettes eszközei. Magyar Közigazgatás, Vol. 2. No. 1. pp. 91-105.

Lennert J. (2020) A távmunka széleskörú elterjedésének lehetséges hatása a magyarországi vándormozgalmi mintázatokra. Tér és Társadalom, Vol. 34. No. 2. pp. 178-182.

Local Government Response Towards Covid-19 Pandemic: a Worldwide Survey and Comparison https://sites.google.com/view/igucgog-covid19/working-papers [Letöltve: 2021. 03. 30.]

Medina, R. Z. \& Diaz, J. C. L. (2016) Social Media Use in Crisis Communication Management: An Opportunity for Local Communities? In: Sobaci, M. Z. (eds) Social Media and Local Governments. Cham: Springer. pp. 321-335. https://doi.org/10.17649/ TET.34.2.3263 [Letöltve: 2021. 07. 07.]

Merchant, R. M., Elmer, S. \& Lurie, N. (2011) Integrating Social Media into Emergency-Preparedness Efforts. New England Journal of Medicine, Vol. 365. No. 4. pp. 289-291. https://www. nejm.org/doi/full/10.1056/nejmpl103591 [Letöltve: 2021. 07 06.]

Mergel, I. (2012) The Social Media Innovation Challenge in the Public Sector. Information Polity, Vol. 17. No. 3. pp. 281-292. https://www.researchgate.net/publication/262360939_The_Social_Media_Innovation_Challenge_in_the_Public_Sector [Letöltve: 2021. 07. 06.]

Moreno, Á., Fuentes-Lara, C. \& Navarro, C. (2020) Covid-19 communication management in Spain: Exploring the effect of information-seeking behavior and message reception in public's evaluation. El profesional de la información, Vol. 29. No. 4. https://doi. org/10.3145/epi.2020.jul.02 [Letöltve: 2021. 03. 30.]

Neely, R. S. \& Collins, M. (2018) Social Media and Crisis Communications: A Survey of Local Governments in Florida. Journal of Homeland Security and Emergency Management, Vol. 15. No. 1. pp 1-13. https://ideas.repec.org/a/bpj/johsem/v15y2018ilpl3n3. html [Letöltve: 2021. 07. 06.]

Neuendorf, K. A. (2002) The Content Analysis Guidebook. London: Sage Publications

Oláh M. (2020) Autonómia, ambíció, alkalmasság, avagy kik irányítják közügyeinket helyben? In: Zongor G. (ed.) Veszprém megyei önkormányzati almanach 1990-2020. Veszprém: Comitatus Könyvek. pp. 197-208. http://www.mrtt.hu/files/comitatus/veszprem_almanach.pdf [Letöltve: 2021. 07.07.]

Pálné Kovács I. (2013) Dilemmák a jó kormányzás és a decentralizáció összefüggéseiről. http://www.regscience.hu:8080/xmlui/bitst$\mathrm{ream} /$ handle/11155/347/palne_dilemmak_2013.pdf [Letöltve: 2021. 03. 30.]

Pálné Kovács I. (2016) Modellváltás a magyar önkormányzati rendszerben. In: Jakab A. \& Gajduschek Gy. (eds.) A magyar jogrendszer állapota. Budapest: MTA Társadalomtudományi Kutatóközpont. pp. 583-599. https://jog.tk.hu/uploads/files/A_magyar_ jogrendszer_allapota_2016.pdf [Letöltve: 2021. 07. 01.]

Pálné Kovács I. (2019) Bizalom és helyi kormányzás. Elméleti és hazai dilemmák. Politikatudományi Szemle, Vol. 28. No. 3. pp. 31-53.

Pálné Kovács I. (eds) (2020) Önkormányzati szerepek a koronavírus járvány kezelésében. Pécs: MTA KRTK Regionális Kutatások Intézete

Park, S., Han, S., Kim, J., Molaie, M. M., Vu, H. D., Singh, K. ... Cha, M. (2020) Risk Communication in Asian Countries: COVID-19 Discourse on Twitter. https://arxiv.org/abs/2006.12218 [Letöltve: 2021. 03. 30.]

Rákóczi Zs. (2006) Társadalmi felelősség a közigazgatási kommunikációban. Tudásmenedzsment, Vol. 7. No. 1. pp. 19-23.

Rákóczi Zs. (2009) Az önkormányzati kommunikáció szerepe. Tudásmenedzsment, Vol. 10. No. 2. pp. 63-68.

Skorka T. (2021) Koronavírus a szabálysértés szemszögéből. Magyar Rendészet, Vol. 21. No. 1. pp. 99-115.

Snelson, C. L. (2016) Qualitative and Mixed Methods Social Media Research: A Review of the Literature. International Journal of Qualitative Methods, Vol. 15. No. 1. pp. 1-15. https://doi. org/10.1177/1609406915624574 [Letöltve: 2021. 07. 05.]

Sobaci, M. Z. (2016) Social Media and Local Governments: An Overview. In: Sobaci, M. Z. (eds) Social Media and Local Governments. Cham: Springer. pp. 3-22. https://ideas.repec.org/h/spr/ paitcp/978-3-319-17722-9_1.html [Letöltve: 2021. 07.07.]

Szirmai V. (2021) Nagyvárosok a COVID-19 vírusjárvány idején. Földrajzi Közlemények, Vol. 145. No. 1. pp. 1-16. https://doi. org/10.32643/fk.145.1.1 [Letöltve: 2021. 07. 05.]

Thomas, J. \&Tunney, S. (2019) Analysing and evaluating websites: locating public health within an international multi-disciplinary review of published research. International Journal of Perceptions in Public Health, Vol. 3. No. 2. pp. 43-54.

Torneo, A. R. \& Berse, K. (2020) Setting up a COVID-19 Community Response Strategy in Local Government Units: Immediate, Transitory, and Medium-Term Considerations for Planning. De La Salle University Policy Brief, 2. https://www.researchgate.net/ publication/343127916_Setting_up_a_COVID-19_Community_ 
Response_Strategy_in_Local_Government_Units_Immediate Transitory_and_Medium-Term_Considerations_for_Planning [Letöltve: 2021. 03. 30.]

Tóth I. Gy. \& Hudácskó Sz. (2020) A koronavírus-járvány társadalmi hatásai a közvélemény-kutatások tükrében. In: Kolosi T., Szelényi I. \& Tóth I. Gy. (eds) Társadalmi Riport. Budapest: Tárki. pp. 553571.

Uzzoli A., Kovács S. Zs., Páger B. \& Szabó T. (2021) A hazai COVID-19-járványhullámok területi különbségei. Területi Statisztika, Vol. 61. No. 3. pp. 291-319. https://www.ksh.hu/statszemle_archive/terstat/2021/2021_03/ts610302.pdf [Letöltve: 2021. 07. 07.]

Varjú V., Farkas O., Farkas J. Zs. \& Vér Cs. (2020) Az egyéni munkacélú személygépkocsi-közlekedés COVID-19 járvány következtében történő változásának néhány környezeti aspektusa Budapesten. Tér és Társadalom, Vol. 34. No. 2. pp. 183-188.

Yang, Y., Deng, W., Zhang, Y. \& Mao, Z. (2021) Promoting Public Engagement during the COVID-19 Crisis: How Effective Is the Wuhan Local Government's Information Release? International Journal of Environmental Research and Public Health, Vol. 18. No. 1. https://doi.org/10.1016/j.giq.2020.101539 [Letöltve: 2021. 03. 30.]

Zeemering, E. S. (2021) Functional fragmentation in city hall and Twitter Communication during the COVID-19 Pandemic: Evidence from Atlanta, San Francisco, and Washington, DC. Government Information Quarterly, Vol. 38. No. 1. https://doi. org/10.1016/j.giq.2020.101539 [Letöltve: 2021. 03.30.]

\section{Jogszabályok}

2020. évi CIX. törvény a koronavírus-világjárvány második hulláma elleni védekezésről. Magyar Közlöny, 2020/242. szám, 2020. november 10. http://www.kozlonyok.hu/nkonline/index.php?men uinde $=200$ \&pageindex $=$ kozltart $\&$ ev $=2020 \&$ szam $=242$

2020. évi XII. törvény a koronavírus elleni védekezésról. Magyar Közlöny, 2020/58. szám, 2020. március 30. http://www.kozlonyok $\mathrm{hu} /$ nkonline $/$ index.php? $m e n u i n d e x=200 \&$ pageindex $=$ kozltart\&e $\mathrm{v}=2020 \&$ szam $=58$

$135 / 2020$. (IV. 17.) Korm. rendelet a veszélyhelyzettel összefüggésben a nemzetgazdaság stabilitásának érdekében szükséges intézkedésekről. Magyar Közlöny, 2020/79. szám, 2020. április 17. http://www.kozlonyok.hu/nkonline/index.php?menuindex $=200$ \&pageindex $=$ kozltart\&ev $=2020 \&$ szam $=79$

$92 / 2020$. (IV. 6.) Korm. rendelet a Magyarország 2020. évi központi költségvetésének a veszélyhelyzettel összefüggő eltérő szabályairól. Magyar Közlöny, 2020/66. szám, 2020. április 6. http://www. kozlonyok.hu/nkonline/index.php? $m e n u i n d e x=200 \& p a g e i n d e x=$ kozltart\&ev $=2020 \&$ szam $=66$
2020. évi LIX. törvény a különleges gazdasági övezetről és a hozzá kapcsolódó egyes törvények módosításáról. Magyar Közlöny, 2020/144. szám, 2020. június 17. http://www.kozlonyok.hu/ nkonline /index.php? $m e n u i n d e x=200 \&$ pageindex $=$ kozltart\&ev $=2$ 020\&szam $=144$

2011. évi CXXVIII. törvény a katasztrófavédelemrôl és a hozzá kapcsolódó egyes törvények módosításáról. Magyar Közlöny, 2011/ 131. szám, 2011. november 10. http://www.kozlonyok.hu/ nkonline/mkpdf/hiteles/mkl1131.pdf

2011. évi CLXXXIX. törvény Magyarország helyi önkormányzatairól. Magyar Közlöny, 2011/161. szám, 2011. december 28. https:// magyarkozlony.hu/dokumentumok/6c55el3d785a906639b476f d7178ff26dc9b5274/megtekintes

1012/2020. (I. 31.) Korm. határozat a Koronavírus-járvány Elleni Védekezésért Felelős Operatív Törzs felállításáról. Magyar Közlöny, 2020/16. szám, 2020. január 31. http://www.kozlonyok.hu/ nkonline /index.php? menuindex $=200 \&$ pageindex $=$ kozltart\&ev $=2$ 020\&szam $=16$

\section{Internetes források}

Covid-19 visszatekintés: a média felülírta a tényadatokat. 2021. 06. 17. https://www.ipsos.com/hu-hu/covid-19-visszatekintes-mediafelulirta-tenyadatokat

Európai Bizottság (2021): Európa digitális évtizede: a 2030-ra kitúzött célok. https://ec.europa.eu/info/strategy/priorities2019-2024/europe-fit-digital-age/europes-digital-decade-digitaltargets-2030_hu

Koronavírus: az operatív törzs március 16-i sajtótájékoztatója. 2020. 03. 16. https://index.hu/video/2020/03/16/koronavirus_operativ_torzs_sajtotajekoztato_elo_kozvetites_facebook_live/

Napokon belül megtöbbszöröződhet a fertőzöttek száma: az Operatív Törzs sajtótájékoztatója. 2020. 03. 17. https://index.hu/vi$\mathrm{deo} / 2020 / 03 / 17 /$ koronavirus_operativ_torzs_sajtotajekoztato_ elo_kozvetites_facebook_live/

Összesített, települési szintű fertőzöttségi adatokat kaptunk Müller Cecíliától. 2021. 02. 24. https://k.blog.hu/2021/02/24/oszszesitett_telepulesi_szintu_fertozottsegi_adatokat_kaptunk_muller_ceciliatol

A K-Monitor megkapta a települési COVID-halálozási adatokat. 2021. 05. 29. https://k.blog.hu/2021/05/29/covid-telepulesi

Budapesten 60 százalékos az oltottság, Borsodban és Szolnok megyében nem éri el az 50-et. 2021. 07. 13. https://444.hu/ 2021/07/13/budapesten-60-szazalekos-az-oltottsag-borsodbanes-szolnok-megyeben-nem-eri-el-az-50-et

Müller Cecília nem tudja, hol hány embert oltottak be az ország különböző pontjain. 2021. 06. 20. https://444.hu/2021/06/20/muller-cecilia-nem-tudja-hany-embert-oltottak-be-az-orszag-kulonbozo-pontjain

A cikk a Creative Commons Attribution 4.0 International License (https://creativecommons.org/licenses/by-nc/4.0/) feltételei szerint publikált Open Access közlemény, melynek szellemében a cikk bármilyen médiumban szabadon felhasználható, megosztható és újraközölhető, feltéve, hogy az eredeti szerző és a közlés helye, illetve a CC License linkje és az esetlegesen végrehajtott módosítások feltüntetésre kerülnek. 